\title{
Correction to: Flash glucose monitoring and glycemic control in type 1 diabetes with subcutaneous insulin infusion
}

\author{
Sara Lomelino Pinheiro ${ }^{1}$ (D ) Margarida Bastos ${ }^{2} \cdot$ Luísa Barros $^{2} \cdot$ Miguel Melo $^{2} \cdot$ Isabel Paiva $^{2}$
}

Published online: 8 January 2022

(c) Springer-Verlag Italia S.r.l., part of Springer Nature 2022

\section{Correction to: Acta Diabetologica \\ https://doi.org/10.1007/s00592-021-01827-2}

Authors would like to correct the article title which was incorrectly published in original version.

The original article has been corrected.

Publisher's Note Springer Nature remains neutral with regard to jurisdictional claims in published maps and institutional affiliations.

The original article can be found online at https://doi.org/10.1007/ s00592-021-01827-2.

Sara Lomelino Pinheiro

saralomelinopinheiro@gmail.com

1 Department of Endocrinology, Instituto Português de

Oncologia de Lisboa, Lisbon, Portugal

2 Department of Endocrinology, Diabetes and Metabolism,

Centro Hospitalar Universitário de Coimbra, Coimbra,

Portugal 